Ritesh Patel *

\section{Pre \& Post-Merger Financial Performance: An Indian Perspective}

\begin{abstract}
The paper compares the before and after merger position of long term profitability with respect to selected Indian banks for a period of 2003-04 to 2013-2014. The financial performance is evaluated on the basis of various variables. The study found a negative impact of merger on return on equity, return on assets, Net profit ratio, yield on advance and yield on investment. However, variables, namely, the Earnings per Share, Profit per employee and Business per employee have shown positive trend and grown after the merger. It has been observed that after the merger, the Assets, Equity, Investment and advances of all banks increases, but due to underutilization, their respective yield decreases. On a contrary, the business per employee and profit per employee have increased due to optimum utilization of human resources. By applying the Comparative Analysis, the paper also assesses the financial performance of acquiring bank with the banking industry. The Bank of Baroda and Oriental bank of commerce has found decreases in Yield on Advances and yield on investment as compared to average of all banks in the postmerger period. State bank of India \& IDBI Bank has higher business per employee and profit per employee as compared to industry average.
\end{abstract}

Key Words: Merger, Financial performance, Bank, India

JEL classification code: G21, G34
${ }^{*}$ Department of Management, Nirma University, Ahmedabad, Gujarat, India

E-mail:

ritesh@nirmauni.ac.in, prof.ritesh2010@gmail.com 


\section{Introduction}

The Indian banking industry plays a vital role in the economic development of the country. The Indian banking industry has witnessed many reforms in last three decades. The banking industry is divided into two categories, namely, Scheduled commercial banks and Non-scheduled commercial banks. The banks registered as per the Schedule II of the reserve bank of India act, 1934 are known as scheduled commercial banks, which further categorized as Public-sector banks, Private sector banks and foreign banks. The Nationalized banks, State bank of India and its associate banks, Regional Rural Banks fall in the category of a public sector bank. The Private sector banks include the old Private sector banks and new Private sector banks. The regional rural banks are sponsored by particular bank, state government and central government and working in rural areas.

The Merger and acquisition are one of the important tools to achieve the growth. The merger as per the Godbole (2013) is the "combination of all the assets, liabilities, loans \& business of two or more companies such that one of them survives." Many firms across the globe have adopted the strategy of merger and acquisition to achieve high growth in business. Further, the merger and acquisition also serve the purpose of expansion, reducing the level of competition and creation of a large entity.

According to Narayanswamy (2017) the financial analysis is a technique to study the annual report of company to provide relevant information to the decision makers. Acquiring firm always needs to check financial performance of the target firm as merger affects the financial position and wealth of all stakeholders. Since merger can have significant impact on financial performance of the acquiring firm in any of the ways, i.e. either positive or negative, the acquirer needs to evaluate the target firm in well manner before going for merger deal. Again, the merger can result in poor financial performance.

There are five different forms of merger. Vertical Merger is a merger of non-competing companies where one's product is a necessary component of other's. Such merger can be done between two firms engaged in different aspects of business. Horizontal merger involves two firms that operate and compete in the same kind of business activity. The acquiring firm belongs to the same industry as the target company. Accretive Merger occurs when a company with a high price-to-earnings ratio purchases a company with a low price-to-earnings ratio. If there is no economic relationship between the acquiring \& acquired firm, such a merger is known as Conglomerate merger. A merger is dilutive one if the EPS of acquiring company falls after merger. This happens due to poor financial performance of target firm. 
The paper is arranged as follows: section 2 presents the literature review of preand post-merger financial performance. The research methodology is covered in section 3. The data analysis of the selected financial parameters is depicted in section 4 . The conclusion is covered in section 5 .

\section{Literature review}

The literature on pre- and post-merger financial performance has been used in recent times. A review of many studies carried out in many countries across the globe is presented here. Many researchers have found a positive impact of merger on financial performance.

Harrison et al. (1991) analyse the post-acquisition performance of 1100 US firms in the period of 1970-1989 and demonstrates that the acquisition remains beneficial for the acquiring firms \& resulted in improvement of profitability ratios. Lees (1992) finds that the merger remains beneficial for the acquiring firm and in the post-merger period the profitability has increased with higher rate as compared to the pre-merger period. Shanmugam and Nair (2004) analysed the impact of merger on financial performance of 54 Malaysian banks. By applying the paired t-test on 1990-2000 data, it is found that merger has strengthened the financial position of banks and resulted in improvement in profitability ratios. Feroz et al. (2005) finds that financial performance enhanced significantly after merger. The financial ratios are in improved version after merger. Mumcu and Zenginobuz (2005) examine the pre- and post-merger financial performance of the Turkish banking industry. They find that merger has significant and positive impact on financial performance and resulted in improved profitability. Demirbag et al. (2007) analyse the impact of merger on financial performance of Indian pharmaceutical firms. The study finds that the merger remains positive from the financial point of view and ensued in increases in Return on investment and Net profit margin. Ramakrishnan (2008) finds that the merger that happened in the Indian financial sector from 1996 to 2003 led to improvement in financial performance of firms and also contributed towards brisk growth. In another study, Ramakrishnan (2010) examines the impact of merger on financial performance of Indian firms using data from 1996 to 2002. The study came with the outcome that the mergers have enhanced the long-term performance of firms. Kilic (2011) examines the pre- and post-merger financial performance of 10 Turkish banks using data envelopment analysis and finds positive impact of merger on profitability. After the merger, the financial performance improved pointedly. Dobre et al. (2012) assess financial performance of Romanian corporate firms covering the period of 2005-2011. They find that the merger resulted in the improve- 
ment of financial performance and, as a result, the profitability ratios increased significantly. Francoeur et al. (2012) using the 1990 to 2003 data of Canadian firms, finds that the merger improves the profitability. The profitability ratios increases significantly after the merger and shows better results. Meghouara and Sbai (2013) find that the merger of the commercial bank of morocco remains beneficial. The profitability ratio increased significantly after the merger. Reddy et al. (2013) investigate the pre- and post-merger financial performance of Indian banks covering a period from 2000 to 2006 . The study finds that the merger remains positive for the financial performance. Ahmed and Ahmed (2014) assess the financial performance of Pakistani manufacturing companies covering a period of 2000-2009. They find that the merger resulted in improving the overall performance of the firm. Further, after the merger, there is significant improvement in profitability and the merger remains positive. Arvanitis and Stucki (2015) analyses the pre- and post-merger financial performance of mergers that happened among small and medium sized firms in Switzerland during 20082010. The study revealed that the merger had a positive impact on financial performance and the profitability ratios showed improved performance. Joash and Njangiru (2015) by using the data from 2000 to 2014, come to the conclusion that the merger remains positive for Kenyan banks. After the merger, the Return on investment \& earning per share have increased significantly. Rani et al. (2015) analyses the pre- and post-merger financial performance of 305 Indian firms using a paired t-test. The study finds that after the merger the financial performance has upgraded and Return on equity, Return on capital employed, the Net profit margin increased significantly. Daniya et al. (2016) examine the pre- and postmerger financial performance of 24 Nigerian banks and concludes that the after the merger the financial performance improved and, as a result, the profitability ratios increased significantly. Al-Hroot (2016) using the paired sample t-test on seven different Jordanians firms finds that the merger resulted in improving the overall performance of the firm. Das (2014) studied the pre- and post-merger financial performance of regional rural banks using a paired t-test. The study finds that the merger has a positive impact on financial performance and increases profitability significantly. Patel and Shah (2016) investigate the pre- and postmerger financial performance of the Indian banking industry covering a period of 2001 to 2014. They find the impact of merger to be positive and significant for financial performance.

Some of the researchers have found an average impact of merger on the financial performance where profitability has improved but not to a significant extent. $\mathrm{Pa}$ waskar (2001) analyses the merger of Indian corporates involved in the merger activities during 1996 to 2000 . He found that the merger does not lead to any improvement in financial performance and remains average. Kumar and Bansal 
(2008) analyse the financial performance of 74 companies using correlation and chi-square test. The Study finds that the merger improved the financial performance but not significantly. Kumar (2009) assesses the impact of merger on financial performance with respect to Indian manufacturing firms covering data from 1999-2002. The Study concludes that the merger does not result in significant improvement in financial performance. Uddin and Boateng (2009) investigate the pre- and post-merger financial performance of 373 firms. The study finds that the merger affects financial performance positively, but not to a significant extent. Sufian et al. (2012) examines the pre- and post-merger financial performance of Malaysian banks using data covering the period from 1996 to 2009. The study finds that there is no significant difference in financial performance after the merger. Ghosh and Dutta (2014) investigate the performance of 10 telecom companies covering the period from 2000 to 2010. The study finds that there is some improvement in financial performance after the merger. Jayaraman et al. (2014) analyses the pre- and post-merger financial performance of Indian banks covering the period of 2001 to 2013 . They find that the merger does not have any significant impact on financial performance in the initial period but from the third year the profitability shows an increasing trend. Duggal (2015) examines the pre- and post-merger financial performance in Indian pharma firms covering the 2000-2006 period. The study finds that the merger remains somewhat beneficial as after the merger the profitability ratios have improved for a period of one year only, i.e. short term period. Patel and Patel (2015) examine the impact of merger on four Indian banks during 2005-2012. They find that the merger has improved the performance but to a limited extent. Rashid and Naeem (2017) analyse the pre- and post-merger financial performance of 25 Pakistani corporate firms covering the period from 1995 to 2012. They find that the merger does not have any significant impact on financial performance and there is some improvement in the profitability ratios.

Some researchers have found a negative impact of merger on the financial performance. Mantravadi and Reddy (2008) analysed the pre- and post-merger financial performance of Indian firms using paired t-test covering a period from 1991-2003. They find that the merger remains negative for the financial performance and resulted into decreasing in various profitability ratios. In another study, Mantravadi and Reddy (2008) using the data of 68 Indian firms, come to a conclusion that the mergers that happened among the banking and financial service firms remained somewhat beneficial and resulted in marginal improvement in profitability. Kemal (2011) analyses the pre- and post-merger financial performance of 2 Pakistani banks covering the period of 2006 to 2009 . The study finds that the merger deal fails to improve the financial performance and results in decrease in the level of profitability. Lakstutiene et al. (2015) analyse the post- 
acquisition performance of 10 corporate firms based in Lithuania. They covered a period of 2000 to 2010 and find that the merger had a negative impact on financial performance of the firms. After the merger, the profitability ratios decreased in the short run. Vulanovic (2017) finds that the merger has negative impact on the financial performance of industrial firms. The firms engaged in the merger have reported negative outcome in the financial performance. Igbinosa et al. (2017), Singh \& Bansal (2017) and Shijaku (2017) found the financial ratios as an important tool to measure the performance.

To date, studies of pre- and post-merger financial performance only considered financial ratios but few variables have not been included. These variables are pertaining to the banking industry only. This study is considering the variables which can give better results. Based on the literature review, the variables and statistical test are drawn for carrying out this study.

\section{Research Methodology}

This study is carried out with the objective to know the before- and after-themerger comparative position of long term profitability with respect to the selected Indian banks. Further, the study also aims to analyse the financial performance of the selected banks with the average of the industry in both pre- and post-merger. This study uses five years before and five years after the merger event to test the hypothesis. Total duration of eleven years is taken into consideration. The year of merger is designated as (T0) whereas the five years before and after the merger are shown as (-T5, -T4, -T3, -T2, -T1) and (T1, T2, T3, T4, T5), respectively. This study is carried out using a descriptive research design. The study is carried out by using the Basic research approach.

\subsection{Data}

Here five banks, namely Bank of Baroda, IDBI Bank, Indian Overseas Bank, Oriental Bank of Commerce and State bank of India are selected as per the following criteria.

- Banks belong to the public sector

- Banks have domestic merger

- Banks involved in merger and acquisition activity during 2002 to 2010

- Accounting data and financial ratios of the sample banks are available 
The data contain the profitability ratios, balance sheet and profit and loss account. The reliable data are taken from ACE Equity database software, Reports and Publications of Reserve Bank of India, Centre for Monitoring Indian Economy (CMIE), and Reports and Publications of Indian Banker's associations. The sample banks are selected using the judgmental sampling method.

\subsection{Variables and Hypothesis}

To perform the financial analysis, various ratios and variables such as Business per Employee, earnings per share, net profit margin, profit per employee, return on assets, return on equity, yield on advances and yield on investments are used. These variables were selected by various researchers in the past, for example Harrison et al. (1991), Lees (1992), Pawaskar (2001), Shanmugam and Nair (2004), Feroz et al. (2005), Mumcu and Zenginobuz (2005), Demirbag et al. (2007), Kumar and Bansal (2008), Mantravadi and Reddy (2008), Ramakrishnan (2008), Kumar (2009), Uddin and Boateng (2009), Ramakrishnan (2010), Kemal (2011), Kilic (2011), Dobre et al. (2012), Francoeur et al. (2012), Reddy et al. (2013), Sufian et al. (2012), Meghouara and Sbai (2013), Ahmed and Ahmed (2014), Ghosh and Dutta (2014), Jayaraman et al. (2014), Duggal (2015), Joash and Njangiru (2015), Lakstutiene et al. (2015), Patel and Patel (2015), Rani et al. (2015), Daniya et al. (2016), Al-Hroot (2016), Das (2014), Patel and Shah (2016), Rashid and Naeem (2017) and Vulanovic (2017). The business per employee and profit per employee are variables which concern only the banking industry. But as these variables are important in order to evaluate the financial performance with respect to human resources, the present study considers these variables.

Here, a paired $t$-test is used to check the before- and after-the-merger comparative position of long term profitability. The paired t-test is considered as important to check the comparative positive and used by various researchers in the past, for example Harrison et al. (1991), Pawaskar (2001), Shanmugam and Nair (2004), Mumcu and Zenginobuz (2005), Demirbag et al.(2007), Mantravadi and Reddy (2008), Ramakrishnan (2008), Kumar (2009), Uddin and Boateng (2009), Ramakrishnan (2010), Kemal (2011), Dobre et al. (2012), Francoeur et al. (2012), Reddy et al. (2013), Sufian et al. (2012), Meghouara and Sbai (2013), Ahmed and Ahmed (2014), Ghosh and Dutta (2014), Jayaraman et al. (2014), Duggal (2015), Joash and Njangiru (2015), Lakstutiene et al. (2015), Patel and Patel (2015), Rani et al. (2015), Daniya et al. (2016), Al-Hroot (2016), Das (2014), Patel and Shah (2016), Rashid and Naeem (2017) and Vulanovic (2017). 
The variable wise hypotheses for performing the paired t-test are listed as below. Here, the period before merger and the period after merger are characterized as BM \& AM, respectively.

Table 1: Variable wise hypothesis

\begin{tabular}{llc}
\hline \multicolumn{1}{c}{ Variable } & Null Hypothesis & Alternative Hypothesis \\
\hline Return on Equity (ROE) & $\mathrm{ROE}_{\mathrm{BM}}=\mathrm{ROE}_{\mathrm{AM}}$ & $\mathrm{ROE}_{\mathrm{BM}} \neq \mathrm{ROE}_{\mathrm{AM}}$ \\
\hdashline Return on Assets (ROA) & $\mathrm{ROA}_{\mathrm{BM}}=\mathrm{ROA}_{\mathrm{AM}}$ & $\mathrm{ROA}_{\mathrm{BM}} \neq \mathrm{ROA}_{\mathrm{AM}}$ \\
\hline Earnings per Share (Rs). (EPS) & $\mathrm{EPS}_{\mathrm{BM}}=\mathrm{EPS}_{\mathrm{AM}}$ & $\mathrm{EPS}_{\mathrm{BM}} \neq \mathrm{EPS}_{\mathrm{AM}}$ \\
\hline Yield on Advances (YOA) & $\mathrm{YOA}_{\mathrm{BM}}=\mathrm{YOA}_{\mathrm{AM}}$ & $\mathrm{YOA}_{\mathrm{BM}} \neq \mathrm{YOA}_{\mathrm{AM}}$ \\
\hdashline Yield on Investments (YOI) & $\mathrm{YOI}_{\mathrm{BM}}=\mathrm{YOI}_{\mathrm{AM}}$ & $\mathrm{YOI} \mathrm{BM}_{\mathrm{BM}} \neq \mathrm{YOI}_{\mathrm{AM}}$ \\
\hline Net Profit Ratio (NP) & $\mathrm{NP}_{\mathrm{BM}}=\mathrm{NP}_{\mathrm{AM}}$ & $\mathrm{NP}_{\mathrm{BM}} \neq \mathrm{NP}_{\mathrm{AM}}$ \\
\hline Profit per Employee (PPE) & $\mathrm{PPE}_{\mathrm{BM}}=\mathrm{PPE}_{\mathrm{AM}}$ & $\mathrm{PPE}_{\mathrm{BM}} \neq \mathrm{PPE}_{\mathrm{AM}}$ \\
\hline Business per Employee (BPE) & $\mathrm{BPE}_{\mathrm{BM}}=\mathrm{BPE}_{\mathrm{AM}}$ & $\mathrm{BPE}_{\mathrm{BM}} \neq \mathrm{BPE}_{\mathrm{AM}}$ \\
\hline
\end{tabular}

Source: Author's creation

\section{Result and discussion}

The study is performed using two different sets of analysis. 1) The pre- and postmerger financial performance measurement 2) Comparative Analysis

\subsection{The pre- and post-merger financial performance measurement}

Each variable here is compared on the basis of the average value of five years before and five years after the merger, respectively. The results of all five banks are depicted below. 


\section{Bank of Baroda}

Table 2: Pre- and post-merger financial performance of Bank of Baroda

\begin{tabular}{|c|c|c|c|c|c|}
\hline Particulars & Duration & Mean & $\begin{array}{l}\text { Standard } \\
\text { Deviation }\end{array}$ & t-value & Sig. \\
\hline \multirow{2}{*}{ Earnings Per Share (Rs.) } & Pre-Merger & 20.84 & 9.06 & \multirow{2}{*}{-3.72} & \multirow{2}{*}{0.020} \\
\hline & Post-Merger & 34.90 & 16.15 & & \\
\hline \multirow{2}{*}{ Yield on Advances (\%) } & Pre-Merger & 18.89 & 2.04 & \multirow{2}{*}{12.92} & \multirow{2}{*}{0.0002} \\
\hline & Post-Merger & 11.79 & 1.75 & & \\
\hline \multirow{2}{*}{ Yield on Investments (\%) } & Pre-Merger & 11.13 & 0.48 & \multirow{2}{*}{6.39} & \multirow{2}{*}{0.003} \\
\hline & Post-Merger & 8.37 & 0.90 & & \\
\hline \multirow{2}{*}{ Return on Assets (\%) } & Pre-Merger & 0.88 & 0.28 & \multirow{2}{*}{0.17} & \multirow{2}{*}{0.86} \\
\hline & Post-Merger & 0.87 & 0.14 & & \\
\hline \multirow{2}{*}{ Return on equity (\%) } & Pre-Merger & 15.81 & 4.64 & \multirow{2}{*}{1.15} & \multirow{2}{*}{0.31} \\
\hline & Post-Merger & 14.10 & 2.69 & & \\
\hline \multirow{2}{*}{ Net Profit Ratio (\%) } & Pre-Merger & 27.88 & 51.62 & \multirow{2}{*}{0.21} & \multirow{2}{*}{0.008} \\
\hline & Post-Merger & 22.26 & 32.12 & & \\
\hline \multirow{2}{*}{ Profit per Employee (Rs. in Lakh) } & Pre-Merger & 0.01 & 0.01 & \multirow{2}{*}{-3.65} & \multirow{2}{*}{0.021} \\
\hline & Post-Merger & 0.03 & 0.02 & & \\
\hline Business per Employee (Rs. in Lakh) & Pre-Merger & 2.05 & 0.48 & -4.19 & 0.013 \\
\hline
\end{tabular}

Source: Author's calculation

Table 2 shows the comparative profitability situation of Bank of Baroda. The average earning per share (EPS) before the merger had been Rs. 20.84 which increased to Rs. 34.90 after the merger. The t-value (-3.72) and significance value (0.020) reveals that after the merger the EPS enhanced significantly. The yield from advances decreased from $18.89 \%$ to $11.79 \%$ after the merger. Further, the t-value (12.92) and significance value (0.0002) divulge the significant impact of merger on yield on advances. The yield on advances decreased due to underutilization of advance in post-merger period. The yield on investment also decreases from $11.13 \%$ to $8.37 \%$. The $t$-value (6.39) and significance value (0.003) shows the significant impact of merger on yield on investment. The yield on investment decreases due to not utilizing the investments in optimum level in the post-merger period. Return on assets does not change with respect to the merger. The reason is proper utilization of assets in both pre- and post-merger period. Return on equity witnessed minor change in post-merger period (14.10\%) as compared to the pre-merger period (15.81\%). The t-value (1.15) and significance value (0.31) shows insignificant impact of merger on return on equity. The net profit ratio decreased from $27.88 \%$ to $22.26 \%$ and the $t$-value $(0.21)$ and significance value $(0.008)$ shows there is significant impact. Profit per employee increases three times after the merger, and $t$-value $(-3.65)$ as well as significance value (0.021) show significant 
impact. The business per employee rose 2.81 times after the merger. The t-value $(-4.19)$ and significance value $(0.013)$ reveal that the merger had significant impact on business per employee. The increase in business per employee and profit per employee shows better utilization of human resources. Overall, the merger has negative impact on Return on equity (\%), Net Profit Ratio, Yield on Advances (\%) \& Yield on Investments (\%) and positive impact on Return on assets, Earnings per Share, Profit per Employee and Business per Employee.

\section{Oriental Bank of Commerce}

Table 3: Pre- and post-merger financial performance of Oriental bank of commerce

\begin{tabular}{|c|c|c|c|c|c|}
\hline Particulars & Duration & Mean & $\begin{array}{l}\text { Standard } \\
\text { Deviation }\end{array}$ & t-value & Sig. \\
\hline \multirow{2}{*}{ Earnings Per Share (Rs.) } & Pre-Merger & 20.20 & 9.86 & \multirow{2}{*}{-1.14} & \multirow{2}{*}{0.031} \\
\hline & Post-Merger & 26.55 & 9.87 & & \\
\hline \multirow{2}{*}{ Yield on Advances (\%) } & Pre-Merger & 22.10 & 3.74 & \multirow{2}{*}{5.91} & \multirow{2}{*}{0.04} \\
\hline & Post-Merger & 12.70 & 0.90 & & \\
\hline \multirow{2}{*}{ Yield on Investments (\%) } & Pre-Merger & 12.88 & 0.52 & \multirow{2}{*}{4.94} & \multirow{2}{*}{0.007} \\
\hline & Post-Merger & 9.47 & 1.04 & & \\
\hline \multirow{2}{*}{ Return on Assets (\%) } & Pre-Merger & 1.27 & 0.38 & \multirow{2}{*}{1.26} & \multirow{2}{*}{0.027} \\
\hline & Post-Merger & 0.93 & 0.39 & & \\
\hline \multirow{2}{*}{ Return on Equity (\%) } & Pre-Merger & 21.59 & 5.57 & \multirow{2}{*}{1.93} & \multirow{2}{*}{0.012} \\
\hline & Post-Merger & 13.77 & 6.62 & & \\
\hline \multirow{2}{*}{ Net Profit Ratio (\%) } & Pre-Merger & 28.91 & 34.24 & \multirow{2}{*}{0.28} & \multirow{2}{*}{0.007} \\
\hline & Post-Merger & 19.94 & 76.27 & & \\
\hline \multirow{2}{*}{ Profit per Employee (Rs. in Lakh) } & Pre-Merger & 0.028 & 0.013 & \multirow{2}{*}{-5.71} & \multirow{2}{*}{0.004} \\
\hline & Post-Merger & 0.056 & 0.005 & & \\
\hline \multirow{2}{*}{ Business per Employee (Rs. in Lakh) } & Pre-Merger & 3.116 & 0.75 & \multirow{2}{*}{-5.65} & \multirow{2}{*}{0.004} \\
\hline & Post-Merger & 7.788 & 2.58 & & \\
\hline
\end{tabular}

Source: Author's calculation

Table 3 shows the comparative profitability situation of Oriental bank of commerce. The EPS increases from Rs. 20.20 to Rs. 26.55 after the merger. The t-value (-1.14) and significance value (0.031) reveals significant improvement in the EPS after the merger. The Yield on Advances is decreased from $22.10 \%$ to $12.70 \%$. The $\mathrm{t}$-value (5.91) and significance value (0.04) divulges the significant impact of the merger. The yield on investment also decreases from $12.88 \%$ to $9.47 \%$. Further, the $t$-value (4.97) and significance value (0.007) shows the significant impact of merger on the yield on investment. The bank has not utilized the investment and advances in optimum level which resulted in decrease in their respective yield. After the merger, the return on assets is decreasing with difference of $0.34 \%$, which is significant as per the t-value (4.97) and significance value (0.027). The 
assets increase after the merger, but due to underutilization, the return on assets decreased in the post-merger period. The Return on Equity witnessed significant decrease in the pre-merger period (21.59\%) and post-merger period (13.77\%). Further, the t-value (1.93) and significance value (0.012) shows the significant impact. The equity increase after the merger but due to underutilization, the return on equity decreased in post-merger period. The Net Profit Ratio witnessed negative impact of the merger where the ratio decreased from $28.91 \%$ to $19.94 \%$, after the merger. The t-value (0.28) and significance value (0.007) show a significant impact on the negative side. The Profit per employee increased after the merger with double value. The t-value (-5.71) and significance value (0.004) show a significant impact of the merger on the positive front. The Business per employee also increased significantly from Rs. (In Lakh) 3.116 to Rs. (In Lakh) 7.788 and it was supported by t-value (-5.65) and significance value (0.004). After the merger, the business per employee and profit per employee increased due to optimum utilization of human resources. Overall, the merger had a negative impact on Return on assets (\%), Return on equity (\%), Net Profit Ratio, Yield on Advances (\%) \& Yield on Investments (\%) and positive impact on Earnings per Share, Profit per employee and Business per employee.

\section{IDBI bank}

Table 4: Pre- and post-merger financial performance of IDBI Bank

\begin{tabular}{|c|c|c|c|c|c|}
\hline Particulars & Duration & Mean & $\begin{array}{l}\text { Standard } \\
\text { Deviation }\end{array}$ & t-value & Sig. \\
\hline \multirow{2}{*}{ Earnings Per Share (Rs.) } & Pre-Merger & 5.40 & 1.60 & \multirow{2}{*}{-6.47} & \multirow{2}{*}{0.0029} \\
\hline & Post-Merger & 12.32 & 3.23 & & \\
\hline \multirow{2}{*}{ Yield on Advances (\%) } & Pre-Merger & 11.25 & 4.04 & \multirow{2}{*}{0.223} & \multirow{2}{*}{0.83} \\
\hline & Post-Merger & 10.79 & 0.81 & & \\
\hline \multirow{2}{*}{ Yield on Investments (\%) } & Pre-Merger & 7.65 & 3.66 & \multirow{2}{*}{0.682} & \multirow{2}{*}{0.532} \\
\hline & Post-Merger & 6.42 & 1.16 & & \\
\hline \multirow{2}{*}{ Return on Assets (\%) } & Pre-Merger & 0.89 & 0.25 & \multirow{2}{*}{2.37} & \multirow{2}{*}{0.076} \\
\hline & Post-Merger & 0.61 & 0.07 & & \\
\hline \multirow{2}{*}{ Return on Equity (\%) } & Pre-Merger & 17.21 & 7.92 & \multirow{2}{*}{1.12} & \multirow{2}{*}{0.032} \\
\hline & Post-Merger & 12.44 & 2.20 & & \\
\hline \multirow{2}{*}{ Net Profit Ratio (\%) } & Pre-Merger & 101.45 & 51.62 & \multirow{2}{*}{2.86} & \multirow{2}{*}{0.0455} \\
\hline & Post-Merger & 25.19 & 19.69 & & \\
\hline \multirow{2}{*}{ Profit per Employee (Rs. in Lakh) } & Pre-Merger & 0.07 & 0.03 & \multirow{2}{*}{-2.05} & \multirow{2}{*}{0.0109} \\
\hline & Post-Merger & 0.09 & 0.02 & & \\
\hline \multirow{2}{*}{ Business per Employee (Rs. in Lakh) } & Pre-Merger & 11.10 & 4.37 & \multirow{2}{*}{-9.27} & \multirow{2}{*}{0.0005} \\
\hline & Post-Merger & 19.98 & 4.20 & & \\
\hline
\end{tabular}

Source: Author's calculation 
Table 4 shows the comparative profitability situation of IDBI Bank. The EPS increased from Rs. 5.40 to Rs. 12.32 after the merger. The t-value (-6.47) and significance value (0.0029) divulge significant improvement in the EPS after the merger. The Yield on Advances is decreased from $11.25 \%$ to $10.79 \%$. The t-value $(0.223)$ and significance value $(0.834)$ reveals an insignificant impact of the merger. The yield on investment also decreases from $7.65 \%$ to $6.42 \%$. Further, the t-value (0.682) and significance value (0.532) shows an insignificant impact of merger on the yield on investment. The bank has underutilized the investment and advances which resulted in decrease in their respective yield. The return on assets decreased from $0.89 \%$ to $0.61 \%$, in the post-merger period. The t-value (2.37) and significance value (0.076) show insignificant impact of the merger. The assets increases after the merger but due to underutilization, the return on assets decreased in the post-merger period. The Return on Equity witnessed a significant decrease in the pre-merger period (17.21\%) and post-merger period (12.44\%). Further, the t-value (1.12) and significance value (0.032) show a significant impact. Equity increased after the merger but due to underutilization, the return on equity decreased in the post-merger period. The Net Profit Ratio witnessed negative impact of the merger where the ratio decreased from $101.45 \%$ to $25.19 \%$, after the merger. The t-value (2.86) and significance value $(0.0455)$ show a significant impact. The Profit per employee increased from Rs. (in Lakh) 0.07 to Rs. (in Lakh) 0.09 after the merger. The t-value (-2.05) and significance value (0.0109) show a significant impact. The Business per employee also increased significantly from Rs. (in Lakh) 11.10 to Rs. (in Lakh) 19.98 which was supported by t-value (-9.27) and significance value (0.0005). After the merger, the business per employee and profit per employee increased due to the optimum utilization of human resources. The merger has the most negative impact on the net profit ratio among all the variables. Overall, the merger remains average from the financial performance point of view. 


\section{Indian Overseas Bank}

Table 5: Pre- and post-merger financial performance of Indian overseas bank

\begin{tabular}{|c|c|c|c|c|c|}
\hline Particulars & Duration & Mean & $\begin{array}{l}\text { Standard } \\
\text { Deviation }\end{array}$ & t-value & Sig. \\
\hline \multirow{2}{*}{ Earnings Per Share (Rs.) } & Pre-Merger & 12.72 & 3.84 & \multirow{2}{*}{-1.39} & \multirow{2}{*}{0.023} \\
\hline & Post-Merger & 17.98 & 5.14 & & \\
\hline \multirow{2}{*}{ Yield on Advances (\%) } & Pre-Merger & 15.84 & 3.40 & \multirow{2}{*}{2.58} & \multirow{2}{*}{0.06} \\
\hline & Post-Merger & 12.51 & 0.96 & & \\
\hline \multirow{2}{*}{ Yield on Investments (\%) } & Pre-Merger & 10.22 & 1.33 & \multirow{2}{*}{3.90} & \multirow{2}{*}{0.017} \\
\hline & Post-Merger & 7.69 & 1.09 & & \\
\hline \multirow{2}{*}{ Return on Assets (\%) } & Pre-Merger & 1.28 & 0.15 & \multirow{2}{*}{1.86} & \multirow{2}{*}{0.13} \\
\hline & Post-Merger & 0.86 & 0.36 & & \\
\hline \multirow{2}{*}{ Return on Equity (\%) } & Pre-Merger & 31.20 & 3.32 & \multirow{2}{*}{5.55} & \multirow{2}{*}{0.005} \\
\hline & Post-Merger & 18.51 & 7.55 & & \\
\hline \multirow{2}{*}{ Net Profit Ratio (\%) } & Pre-Merger & 36.00 & 25.23 & \multirow{2}{*}{1.58} & \multirow{2}{*}{0.018} \\
\hline & Post-Merger & 6.49 & 35.78 & & \\
\hline \multirow{2}{*}{ Profit per Employee (Rs. in Lakh) } & Pre-Merger & 0.03 & 0.01 & \multirow{2}{*}{-1.84} & \multirow{2}{*}{0.013} \\
\hline & Post-Merger & 0.04 & 0.009 & & \\
\hline \multirow{2}{*}{ Business per Employee (Rs. in Lakh) } & Pre-Merger & 3.06 & 1.07 & \multirow{2}{*}{-8.23} & \multirow{2}{*}{0.001} \\
\hline & Post-Merger & 8.33 & 2.47 & & \\
\hline
\end{tabular}

Source: Author's calculation

Table 5 shows the comparative profitability situation of Indian Overseas Bank. The average EPS increased from Rs. 12.72 to Rs. 17.98 after the merger. The tvalue (-1.39) and significance value (0.023) reveal that after the merger, the EPS improved significantly. The yield from advances is decreased from $15.84 \%$ to $12.51 \%$ after the merger. Further, the t-value (2.58) and significance value (0.06) divulge an insignificant impact of the merger on the yield on advances. The yield on advances decreased due to underutilization of advances in the post-merger period. The yield on investment also decreased from $10.22 \%$ to $7.69 \%$. The $t$-value (3.90) and significance value (0.017) shows significant impact of the merger on the yield on investment. The yield on investment decreased due to underutilization of investment in the post-merger period. The return on assets decreased from $1.28 \%$ to $0.86 \%$, which is insignificant as per the t-value (1.86) and significance value (0.13). The assets increased after the merger but due to underutilization, the return on assets decreased in the post-merger period. Return on equity experienced a significant change in the post-merger period (18.51\%) as compared to the pre-merger period (31.20\%). The t-value (5.55) and significance value (0.005) show there is a significant impact of the merger on return on equity. The net profit ratio decreased from $36 \%$ to $6.49 \%$ in the post-merger period. 
Further, t-value (1.58) and significance value (0.018) show a significant impact. Profit per employee increased 1.25 times after the merger. The t-value (-1.84) and significance value (0.013) show a significant impact. Business per employee also increased 2.72 times after the merger. The t-value (-8.23) and significance value (0.001) reveal that the merger had a significant impact on business per employee. Increase in business per employee and profit per employee shows better utilization of human resources. Overall, the merger remains average from the financial performance point of view.

\section{State bank of India}

Table 6: Pre- and post-merger financial performance of State bank of India

\begin{tabular}{|c|c|c|c|c|c|}
\hline Particulars & Duration & Mean & $\begin{array}{l}\text { Standard } \\
\text { Deviation }\end{array}$ & t-value & Sig. \\
\hline \multirow{2}{*}{ Earnings Per Share (Rs.) } & Pre-Merger & 112.92 & 29.73 & \multirow{2}{*}{-0.535} & \multirow{2}{*}{0.62} \\
\hline & Post-Merger & 134.85 & 71.70 & & \\
\hline \multirow{2}{*}{ Yield on Advances (\%) } & Pre-Merger & 11.89 & 1.05 & \multirow{2}{*}{0.56} & \multirow{2}{*}{0.60} \\
\hline & Post-Merger & 11.99 & 0.56 & & \\
\hline \multirow{2}{*}{ Yield on Investments (\%) } & Pre-Merger & 7.36 & 0.95 & \multirow{2}{*}{-0.70} & \multirow{2}{*}{0.519} \\
\hline & Post-Merger & 7.85 & 0.64 & & \\
\hline \multirow{2}{*}{ Return on Assets (\%) } & Pre-Merger & 0.96 & 0.10 & \multirow{2}{*}{2.12} & \multirow{2}{*}{0.100} \\
\hline & Post-Merger & 0.79 & 0.15 & & \\
\hline \multirow{2}{*}{ Return on Equity (\%) } & Pre-Merger & 16.21 & 1.04 & \multirow{2}{*}{2.59} & \multirow{2}{*}{0.060} \\
\hline & Post-Merger & 12.88 & 2.64 & & \\
\hline \multirow{2}{*}{ Net Profit Ratio (\%) } & Pre-Merger & 17.93 & 22.32 & \multirow{2}{*}{0.46} & \multirow{2}{*}{0.016} \\
\hline & Post-Merger & 9.96 & 25.91 & & \\
\hline \multirow{2}{*}{ Profit per Employee (Rs. in Lakh) } & Pre-Merger & 0.03 & 0.01 & \multirow{2}{*}{-3.67} & \multirow{2}{*}{0.02} \\
\hline & Post-Merger & 0.05 & 0.01 & & \\
\hline \multirow{2}{*}{ Business per Employee (Rs. in Lakh) } & Pre-Merger & 4.61 & 1.39 & \multirow{2}{*}{-14.91} & \multirow{2}{*}{0.0001} \\
\hline & Post-Merger & 9.49 & 2.10 & & \\
\hline
\end{tabular}

Source: Author's calculation

Table 6 shows the comparative profitability situation of State bank of India. The EPS increased from Rs. 112.92 to Rs. 134.85 after the merger. The t-value $(-0.535)$ and significance value (0.62) exposes insignificant impact of merger on the EPS. The yield on advances increased from $11.89 \%$ to $11.99 \%$. The t-value $(0.56)$ and significance value (0.60) reveal insignificant impact of the merger. The yield on investment also increased from $7.36 \%$ to $7.85 \%$. Further, the t-value $(-0.70)$ and significance values (0.519) show insignificant impact of the merger on yield on investment. The bank had utilized the investment and advances in an efficient manner which resulted in an increase in their respective yields. The return on assets decreased from $0.96 \%$ to $0.79 \%$. Further, the t-value (2.12) and significance 
value (0.100) reveal an insignificant impact of the merger on the return on assets. The assets increased after the merger but due to underutilization, the return on assets decreased in post-merger period. The Return on Equity witnesses the significant decrease in the pre-merger period (16.21\%) and the post-merger period (12.28\%). Further, the t-value (2.59) and significance value (0.060) shows the insignificant impact. The equity increase after the merger but due to underutilization, the return on equity decreased in post-merger period. The net profit ratio witnessed negative impact of merger where the ratios decreased from $17.93 \%$ to 9.96\%, after the merger. The t-value $(0.46)$ and significance value (0.0166) showed a significant impact. The profit per employee increased from Rs. (in Lakh) 0.03 to Rs. (in Lakh) 0.05 after the merger. The t-value (-3.67) and significance value (0.02) shows a significant impact. The business per employee also increased significantly from Rs. (in Lakh) 11.10 to Rs. (in Lakh) 19.98 which was supported by t-value (-14.91) and significance value (0.0001). After the merger, the profit per employee and business per employee increased due to optimum utilization of human resources. The merger had positive impact on all variables namely, Earnings per Share, Yield on Advances, Yield on investments, Profit per employee and Business per employee. The return on equity and return on assets experienced negative impact of the merger.

\subsection{Comparative Analysis}

A comparative analysis of various financial performance variables of acquiring banks and the banking industry is given with respect to the pre- and post-merger periods. This is done with the objective to analyse the improvement in financial performance in the post-merger period in relation to the industry average. 
Table 7: Comparative analysis of financial variables of sample banks with average of all banks

\begin{tabular}{|c|c|c|c|c|c|c|c|}
\hline Particulars & Period & $\begin{array}{l}\text { Bank of } \\
\text { Baroda }\end{array}$ & $\begin{array}{c}\text { Oriental } \\
\text { bank of } \\
\text { commerce }\end{array}$ & $\begin{array}{l}\text { IDBI } \\
\text { Bank }\end{array}$ & $\begin{array}{l}\text { Indian } \\
\text { Overseas } \\
\text { bank }\end{array}$ & $\begin{array}{c}\text { State } \\
\text { bank of } \\
\text { India }\end{array}$ & $\begin{array}{c}\text { Average } \\
\text { of all } \\
\text { banks }\end{array}$ \\
\hline \multirow{2}{*}{ Earnings Per Share (Rs.) } & Pre-Merger & 20.84 & 20.2 & 5.4 & 12.72 & 112.92 & 32.24 \\
\hline & Post-Merger & 34.9 & 26.55 & 12.32 & 17.98 & 134.85 & 41.84 \\
\hline \multirow{2}{*}{ Yield on Advances (\%) } & Pre-Merger & 18.89 & 22.1 & 11.25 & 15.84 & 11.89 & 16.21 \\
\hline & Post-Merger & 11.79 & 12.7 & 10.79 & 12.51 & 11.99 & 15.99 \\
\hline \multirow{2}{*}{ Yield on Investments (\%) } & Pre-Merger & 11.13 & 12.88 & 7.65 & 10.22 & 7.36 & 10.32 \\
\hline & Post-Merger & 8.37 & 9.47 & 6.42 & 7.69 & 7.85 & 9.83 \\
\hline \multirow{2}{*}{ Return on Assets (\%) } & Pre-Merger & 0.88 & 1.27 & 0.89 & 1.28 & 0.96 & 0.98 \\
\hline & Post-Merger & 0.87 & 0.93 & 0.61 & 0.86 & 0.79 & 0.84 \\
\hline \multirow{2}{*}{ Return on equity (\%) } & Pre-Merger & 15.81 & 21.59 & 17.21 & 31.2 & 16.21 & 21.24 \\
\hline & Post-Merger & 14.1 & 13.77 & 12.44 & 18.51 & 12.88 & 13.48 \\
\hline \multirow{2}{*}{ Net Profit Ratio (\%) } & Pre-Merger & 27.88 & 28.91 & 101.45 & 36 & 17.93 & 38.42 \\
\hline & Post-Merger & 22.26 & 19.94 & 25.19 & 6.49 & 9.96 & 21.43 \\
\hline \multirow{2}{*}{$\begin{array}{l}\text { Profit per Employee } \\
\text { (Rs. in Lakh) }\end{array}$} & Pre-Merger & 0.01 & 0.028 & 0.07 & 0.03 & 0.03 & 0.0284 \\
\hline & Post-Merger & 0.03 & 0.056 & 0.09 & 0.04 & 0.05 & 0.0491 \\
\hline \multirow{2}{*}{$\begin{array}{l}\text { Business per Employee } \\
\text { (Rs. in Lakh) }\end{array}$} & Pre-Merger & 2.05 & 3.116 & 11.1 & 3.06 & 4.61 & 4.243 \\
\hline & Post-Merger & 5.77 & 7.788 & 19.98 & 8.33 & 9.49 & 9.13 \\
\hline
\end{tabular}

Source: Author's calculation

Table 7 presents a comparative analysis of various financial performance variables of acquiring banks and the banking industry. Among all the banks, SBI has higher Earning per share than the average of all banks, in both pre- and post-merger period. Rests of the banks have their EPS below average. The Bank of Baroda and Oriental bank of commerce had higher yield on advances and yield on investment as compared to the average of all banks in the pre-merger period. But in the post-merger period, yield on advances and yield on investment of all the banks fell below average. It further reveals that after the merger, the yield on investment of banks does not grow at the industry average rate. Indian overseas bank and Oriental bank of commerce have found their return on assets and return on equity higher than the average of the industry in both pre- and post-merger period. Interestingly, the Bank of Baroda had a higher Return on assets and return on equity as compared to that of the industry in the post-merger period, which further enhances the improvement in financial performance. Among all the banks, only State bank of India and Indian overseas bank have reported lower net profit ratio as compared to the industry. IDBI Bank and State bank of India have higher profit per employee as compared to the industry in both pre- and post-merger situations. Profit per employee of the Indian overseas bank is higher as compare to average in the pre-merger period, but it falls below 
in post-merger period. Profit per employee of Oriental bank of commerce had been below the average in the pre-merger period and rose above the average in the post-merger period. IDBI Bank and State bank of India have higher business per employee in both pre- and post-merger periods and the rest of the banks fall below average.

\section{Summary and Conclusion}

Using the paired t-test, the paper compares the before and after merger position of long term profitability with respect to the selected Indian banks for the period from 2003/04 to 2013/14. The pre-merger and post-merger financial performance has been measured by selecting certain financial variables. Bank of Baroda, IDBI Bank, Indian Overseas Bank and Oriental Bank of Commerce have experienced a negative impact of the mergers on most of the variables and a positive impact on a few variables. In the post-merger period, the profitability of all four banks decreased. However, for all four banks, the earnings per share, profit per employee and business per employee showed positive trend and have grown after the merger. The State bank of India had a positive impact of the merger on the majority of the variables namely, earnings per share, yield on advances, yield on investments, profit per employee and business per employee. After the merger, assets, equity, investment and advances of all banks increased, but some banks would not able to utilize these resources at the optimum level and it resulted in decrease in their respective yields. After the mergers, the business per employee and profit per employee in all the banks have increased due to optimum utilization of human resources. Overall, Bank of Baroda, IDBI Bank, Indian Overseas Bank and Oriental Bank of Commerce have experienced mix impact of merger where certain variables found a negative impact and some variables found a positive impact. The State bank of India also found a mix impact of merger, but the impact is more towards the positive side. As compared to other banks, the merger of State bank of India had more positive impact on profitability variables. Further, the comparative analysis of various financial performance variables of acquiring bank / acquired banks? and the banking industry is also performed. Bank of Baroda and Oriental bank of commerce experienced decreases in yield on advances and yield on investment as compare to the average of all banks in the post-merger period. IDBI Bank and State bank of India had higher business per employee and profit per employee in both pre- and post-merger periods. 


\section{References}

1. Ahmed, M., and Ahmed, Z. (2014). Mergers and acquisitions: Effect on financial performance of manufacturing companies of Pakistan. MiddleEast Journal of Scientific Research, 21(4): 689-699.

2. Al-Hroot, Y. A. K. (2016). The Impact of Mergers on Financial Performance of the Jordanian Industrial Sector. International Journal of Management \& Business Studies, 6(1): 2230-9519.

3. Arvanitis, S., and Stucki, T. (2015). Do mergers and acquisitions among small and medium-sized enterprises affect the performance of acquiring firms?. International Small Business Journal, 33(7): 752-773.

4. Daniya, A. A., Onotu, S., and Abdulrahaman, Y. (2016). Impact of Merger and Acquisitions on the Financial Performance of Deposit Money Banks in Nigeria. Arabian Journal of Business and Management Review, 6(4): 1-5.

5. Das, S. (2014). Performance Mantra of the Regional Rural Banks: An Evaluation between the Pre-merger and Post-merger Era. Jindal Journal of Business Research, 3(1-2): 14-28.

6. Demirbag, M., Ng, C. K., and Tatoglu, E. (2007). Performance of mergers and acquisitions in the pharmaceutical industry: a comparative perspective. Multinational Business Review, 15(2): 41-62.

7. Dobre, F., Brad, L., Ciobanu, R., Turlea, E., and Caloian, F. (2012). Management performance audit in mergers and acquisitions. Procedia Economics and Finance, 3: 309-314.

8. Duggal, N. (2015). Post-merger performance of acquiring firms: A case study on Indian pharmaceutical industry. International Journal of Research in Management and Business Studies, 2(3): 24-28.

9. Feroz, E. H., Kim, S., and Raab, R. (2005). Performance measurement in corporate governance: do mergers improve managerial performance in the post-merger period?. Review of Accounting and Finance, 4(3): 86-100.

10. Francoeur, C., Ben Amar, W., and Rakoto, P. (2012). Ownership structure, earnings management and acquiring firm post-Merger market performance: evidence from Canada. International Journal of Managerial Finance, 8(2): 100-119.

11. Ghosh, M. S., and Dutta, S. (2014). Mergers and acquisitions: A strategic tool for restructuring in the Indian telecom sector. Procedia Economics and Finance, 11: 396-409.

12. Godbole, P. G., Mergers, A., \& Restructuring, C. (2013). Vikas Publishing House Pvt. Ltd.

13. Harrison, J. S., Hitt, M. A., Hoskisson, R. E., and Ireland, R. D. (1991). Synergies and post-acquisition performance: Differences versus similarities in resource allocations. Journal of Management, 17(1): 173-190. 
14. Igbinosa, S., Sunday, O., \& Babatunde, A. (2017). Empirical Assessment on Financial Regulations and Banking Sector Performance. Journal of Central Banking Theory and Practice, 6(3), 143-155.

15. Jayaraman, A. R., Srinivasan, M. R., and Arunachalam, R. (2014). Impact of merger and acquisition on the efficiency of Indian banks: a prepost analysis using data envelopment analysis. International Journal of Financial Services Management, 7(1): 1-18.

16. Joash, G. O., and Njangiru, M. J. (2015). The effect of mergers and acquisitions on financial performance of banks (a survey of commercial banks in Kenya). International Journal of Innovative Research and Development, 4(8): 101-113.

17. Kemal, M. U. (2011). Post-merger profitability: A case of Royal Bank of Scotland (RBS). International Journal of Business and Social Science, 2(5): 157-162.

18. Kiliç, M. (2011). Cross-border bank acquisitions and banking sector performance: an empirical study of Turkish banking sector. ProcediaSocial and Behavioral Sciences, 24, 946-959.

19. Kumar, R. (2009). Post-merger corporate performance: an Indian perspective. Management Research News, 32(2): 145-157.

20. Kumar, S., and Bansal, L. K. (2008). The impact of mergers and acquisitions on corporate performance in India. Management Decision, 46(10): 1531-1543.

21. Lakstutiene, A., Stankeviciene, J., Norvaisiene, R., and Narbutiene, J. (2015). The Impact of Acquisitions on Corporate Performance Results during the Period of Economic Slowdown: Case of Lithuania. ProcediaSocial and Behavioral Sciences, 213: 455-460.

22. Lees, S. (1992). Auditing mergers and acquisitions-Caveat emptor. Managerial Auditing Journal, 7(4): 6-11.

23. Mantravadi, D. P., and Reddy, A. V. (December, 2008). Post-merger performance of acquiring firms from different industries in India. International Research Journal of Finance and Economics, 22: 192-204.

24. Mantravadi, P., and Reddy, A. V. (October, 2008). Type of merger and impact on operating performance: the Indian experience. Economic and Political Weekly, 6(4): 66-74.

25. Meghouar, H., and Sbai, H. (2013). The Performance of bank mergers and acquisitions: The case of the commercial bank of Morocco and wafabank. La Revue Gestion et Organisation, 5(1): 71-78.

26. Mumcu, A., \& Ünal Zenginobuz, E. (2005). An analysis of mergers and acquisitions in the Turkish banking sector. In Money and Finance in the Middle East: Missed Opportunities or Future Prospects? (pp. 133-162). Online at http://mpra.ub.uni-muenchen.de/191/ accessed as on 18-7-2017 
27. Narayanaswamy, R. (2017). Financial accounting: a managerial perspective. PHI Learning Pvt. Ltd.

28. Patel, R. J., and Patel, M. K. (2015). Does Merger Be Prolific? A Study of Selected Indian Banks. International Journal of Applied Financial Management Perspectives, 4 (3): 1965-1970

29. Patel, R., and Shah, D. (2016). Mergers and Acquisitions -The Game of Profit and Loss: A Study of Indian Banking Sector. Researchers World, 7(3):92-100.

30. Pawaskar, V. (2001). Effect of mergers on corporate performance in India. Vikalpa, 26(1): 19-32.

31. Ramakrishnan, K. (2008). Long-term post-merger performance of firms in India. Vikalpa, 33(2): 47-64.

32. Ramakrishnan, K. (2010). Mergers in Indian industry: performance and impacting factors. Business Strategy Series, 11(4): 261-268.

33. Rani, N., Yadav, S. S., and Jain, P. K. (2015). Financial performance analysis of mergers and acquisitions: evidence from India. International Journal of Commerce and Management, 25(4): 402-423.

34. Rashid, A., and Naeem, N. (2017). Effects of mergers on corporate performance: An empirical evaluation using OLS and the empirical Bayesian methods. Borsa Istanbul Review, 17(1): 10-24.

35. Shijaku, G. (2017). Does Concentration Matter for Bank Stability? Evidence from the Albanian Banking Sector. Journal of Central Banking Theory and Practice, 6(3), 67-94

36. Singh, O., \& Bansal, S. (2017). An Analysis of Revenue Maximising Efficiency of Public Sector Banks in the Post-Reforms Period. Journal of Central Banking Theory and Practice, 6(1), 111-125.

37. Shanmugam, B., and Nair, M. (2004). Mergers and acquisitions of banks in Malaysia. Managerial Finance, 30(4): 1-18.

38. Srinivasa Reddy, K., Nangia, V. K., and Agrawal, R. (2013). Corporate mergers and financial performance: a new assessment of Indian cases. Nankai Business Review International, 4(2): 107-129.

39. Sufian, F., Muhamad, J., Bany-Ariffin, A. N., Yahya, M. H., and Kamarudin, F. (2012). Assessing the effect of mergers and acquisitions on revenue efficiency: Evidence from Malaysian banking sector. Vision, 16(1): $1-11$.

40. Uddin, M., and Boateng, A. (2009). An analysis of short-run performance of cross-border mergers and acquisitions: Evidence from the UK acquiring firms. Review of Accounting and Finance, 8(4): 431-453.

41. Vulanovic, M. (2017). SPACs: Post-merger survival. Managerial Finance, 43(6): 679-699. 